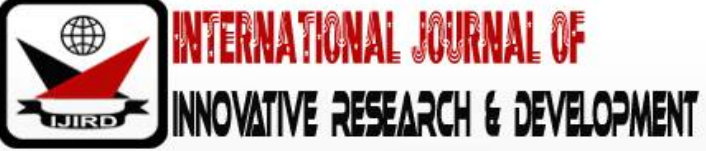

ISSN 2278 - 0211 (Online)

\section{A Suitable Landscape Design for Areas Affected by Gully Erosion in Jos, Plateau State, Nigeria}

\author{
Emmamoge Orewere \\ Lecturer, Department of Horticulture and Landscape Technology \\ Institution: Federal College of Forestry, Jos, Plateau State. \\ Michael Chijioke Odoala \\ Lecturer, Department of Architecture, University of Jos, Plateau State \\ Ruth Ajibola Ogenyi \\ Assistant Lecturer, Department of Science Laboratory Technology, \\ Federal College of Forestry, Jos, Plateau State
}

\begin{abstract}
:
Gullies are a highly visible form of soil erosion, with steep-sided, incised, drainage lines greater than $30 \mathrm{~cm}$ deep. Gully erosion is both a natural and a human-induced process. Landscape design is one of the techniques used in combating this problem. The study is aimed at resuscitating the degraded landscape of areas/ community affected by gully erosion, mining activities, overgrazing, and improper farming over the past years resulting to land unproductively, to satisfy recreational needs, job creation, and participation of community members in programs that support environmental sustainability. It focuses on Tudun Wadaslums settlement located in Jos; the capital of Plateau State situated in the North-Central geopolitical zone of Nigeria. The methodology employed for this study is physical site survey, case study and literature search. The study concludes with land reclamation strategies through landscape design, fencing off a gully system to encourage revegetation and natural recovery, bed stabilization structures and working closely with slum dwellers, allied professionals, and the government to ensure a sustainable development is achieved.
\end{abstract}

Kevwords: Areas, qully erosion, Jos, landscape design

\section{Introduction}

Gully erosion has been recognized as the major cause of land degradation worldwide (Musa, Ahmed, Muhammed and Abdul, 2016) as cited by Igwe, et al., (2018). Gullies are a highly visible form of soil erosion, with steep-sided, incised, drainage lines greater than $30 \mathrm{~cm}$ deep. Gully erosion is both a natural and a human-induced process. Natural gully erosion plays a major role in landscape evolution. Gullies, and the streams that they feed into, help carve out valleys and supply alluvial sediment to fill floodplains (Soil conservation guidelines for Queensland, 2015).

According to Igwe, et al., (2018), in most instances, the development of gullies is caused by overgrazing, road construction and urbanization, log haulage, improper farming and irrigation practices. Gully erosion is important because it affects soil productivity, restricts land use, degrades cultural sites and potable water supplies, and can threaten infrastructure such as roads, fences, access and buildings. As gullies have adirect connection to streams, they have a major impact on water quality. Eroded soil ends up in waterways, road culverts, dams, reservoirs, creeks, rivers and marine environments (Soil conservation guidelines for Queensland, 2015).

Landscape is the art of designing, planning and management of land, arrangement of natural and man-made elements there on, through application of cultural and scientific knowledge with concern for resources conservation so that the resultant environment can serve a useful, healthy and enjoyable purpose(Adekunle, et al., 2016).They further asserted that landscape is one of the most cost effective tools for improving and sustaining the quality of the environment whether in the school environment, the city, the suburbs or the country. Landscaping is an integral part of our culture and plays an essential role in the quality of our environment, economic wellbeing of the people, as well as their physical and psychological health.

Igwe, et al., (2018), posits that landscape as an essential part of the environment which includes topography, vegetation and associated plants and soil, water bodies, is one of the most visual needs of people. An effective landscape is enjoyed by everyone, from residential areas to urban parks. The functionality, the beauty and compatibility with the natural environment are the result of the combined efforts of the landscape designer, the landscape architect and the architect to give an aesthetically pleasing environment (Ayeni, 2012).

According to Dung-Gwom, (2007), the colonial policy of spatial and social segregation laid the foundations to the problems of urban planning and slums development in Jos. The native areas were allowed to grow without formal 
regulation, and due to the up surge of population into Jos for mining, trade and commerce from all over the region and countries areas such as Anguwan Rukuba, Congo Russia, Tudun Wada, Anguwan Rogo, Nasarawa etc. soon became slums characterized by poverty and social exclusion; hazardous locations; overcrowding; lack of basic services etc. (The challenge of slums: global report on human settlements, 2003;UN Habitat report, 2007).

In addition, the negligence use of most abandoned mining sites around the study area of Jos Plateau state Nigeria, has left many of the then mining sites across the state as an eye sow of gully eroded, less productive and continuous deteriorating land mass. This paper is thus focused on measures to substantially reduce the gully erosion and rehabilitate the degraded landscape capable of satisfying recreational needs. The objectives of the study are to: 1) to examine the degraded landscape, conditions and adequacy of space in the community; 2) to investigate the role of landscaping in park development for any community.

\section{Literature Review}

\subsection{Concept of Landscape}

Landscape can be defined from different perspectives depending on the area of interest and

Background. According to (Effobi, 1992), as cited by Olatunde, (2005), landscape can be defined as the portion of land or territory that the human eye can perceive in a single view including all the objects. In the view of (Oduwaye \& Falade, 1998), as cited by Olatunde, (2005), landscape is the combination of mineral geomorphology and the surface mantle, consisting of over burden, topsoil, flora and fauna. Furthermore, landscape deals with the beautification and management of the environment by the organization of space with proper cognizance of the basic principle of design (Ajayi, et al., 2016). Williams and Tilt's study (as cited in Igwe, et al., 2018) opined that an effective landscape design can become an integral part of a good community environment. A well-defined landscape space can enhance the quality of living areas which meets people's preferences.

Landscape design is the art and science of shaping man's natural environment to suit his needs better, as well as restructuring man's man-made environment in order to bring it into closer harmony with nature. Igbozurike, (1986), as cited by Olatunde, (2005). The basic consideration in the design of landscape rest on user's requirement; aesthetic consideration; climatic and environmental consideration and construction and management cost.Ayeni, (2012),asserts that landscapes are composed of elements of different nature which interacts to create a non-random organization in aggregates and pattern. The design material is basically divided into two major categories based on the application and the way they appear. These are soft landscape elements such as the plants i.e. trees, shrubs, flowers, grass, water and earth modeling relates with ecosystem and thus easily available among the elements of landscape (Olatunde,2005; Ayeni, 2012; A Handbook of Landscape, 2013; Adegbie, et al., 2013; Adekunle, et al., 2016) and the hard landscape include inanimate elements that relate with accessibility, of course change the natural surface to paved surfaces such as kerbs, stones, steps, ramps, walls, bricks, concrete, metal, bollards, tiles, walkways, asphalt, paving, planters, sculptures (Olatunde,2005;Ayeni, 2012; A Handbook of Landscape, 2013; Adekunle, et al., 2016). Integrating these elements not only add to the aesthetics but also aid man's visual attraction and comfort within the built environment making it beautiful and functional. Landscaping is an expression of the lifestyle and value of the residents which reflects their personality and their attitudes towards the environment. The search for a qualitative, well landscaped environment, proper use of land and its resources are crucial issues for residential development (Ajayi, et al., 2016). The environment which people live and how it is organized have profound consequences both for the society and individual. Therefore, the need to focus on damage occurring to the natural environmental not only to the present and past landscapes, but to the future landscapes as well.

\subsection{Gully Erosion}

According to Abdulfatai, et al., (2014), gully erosion is an advanced stage of rill erosion where surface channels have been eroded to the point where they cannot be smoothened over by normal tillage operations. Gully erosion often indicates extreme land degradation. Itreduces agricultural productivity by destroying valuable land resources, increases sediment concentrations, reduces water quality, and fills up reservoirs; its rehabilitation has proven to bechallenging especially in the high-rainfall areas Observations have shown clearly that gully erosion is more prevalent in sedimentary terrain than in the basement complex of Nigeria.

Earlier studies like that of Igwe, et al., (2018), indicate that understanding gully erosion mechanism is very important to design the gully erosion measurement system and develop its control. They observed that the use of vegetation to control erosion has been practiced in many countries for centuries. They enumerated some factors to consider when using vegetation to control erosion which include texture and layering of materials, existing vegetation and surface and groundwater movement from upslope and so on. In the view of (Layne, Brien, Demisachew, Jaldesa, Bedasa, and Dereje, 2015), as cited by Igwe, et al., (2018), there are two essential components to managing the erosion problem: rehabilitating the landscape to control the source of soil loss, and reducing sediment flow through the gully system. They argued that gully erosion cannot be stopped completely, especially when gullies receive rushing floods of water from heavy rainfall but that gullies can be treated to achieve long-term suppression of sediment transport, and when combined with better landscape management the erosion can be substantially reduced. Gully erosion is both a natural and a humaninduced process (Soil conservation guidelines for Queensland, 2015).Natural gully erosion plays a major role in landscape evolution. Gullies, and the streams that they feed into, help carve out valleys and supply alluvial sediment to fill floodplains. 


\subsubsection{Components of a Gully}

The various components of a gully are illustrated in Figure 1. They include the head, sides and the bed or floor of a gully. As a gully lengthens, it develops lateral branches. There may be several gully heads advancing up a gully at any one time in what can be called a 'steps and stairs' pattern.

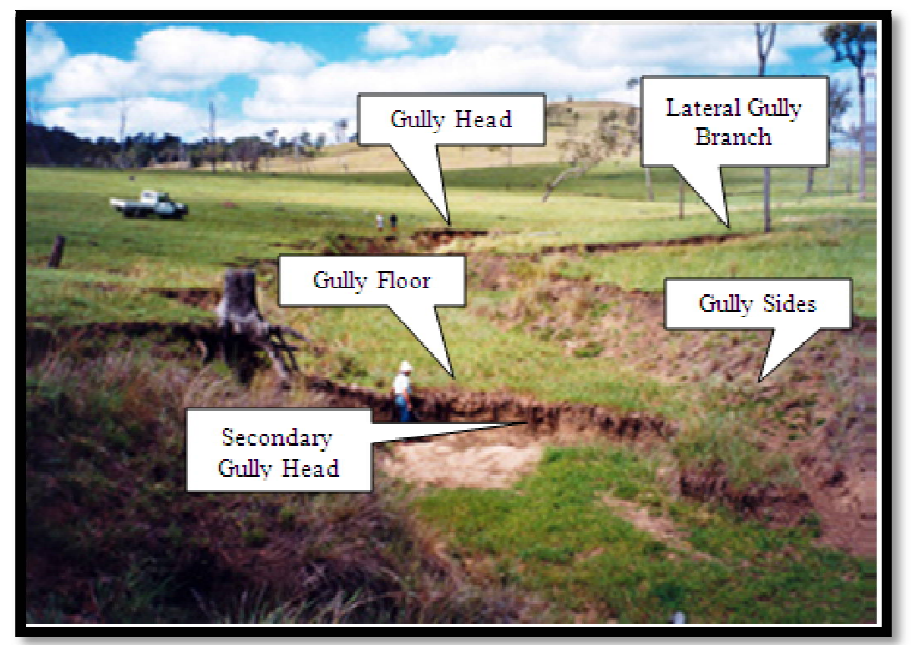

Figure 1: The Components of a Gully

Source: Adapted from Soil Conservation

Guidelines for Queensland, 2015

\subsubsection{Gully Development and Expansion}

Runoff gains energy as it flows over a gully head into a plunge pool, causingvarious gully expansion processes to occur. A gully, like a stream out of balance, attempts to reach a new balance as it goes through processes that may change its length, depth and width.(Soil conservation guidelines for Queensland, 2015). Mining activities can create steep spoil heaps with exposed dispersive subsoil. Such sites are also prone to serious gully erosion.

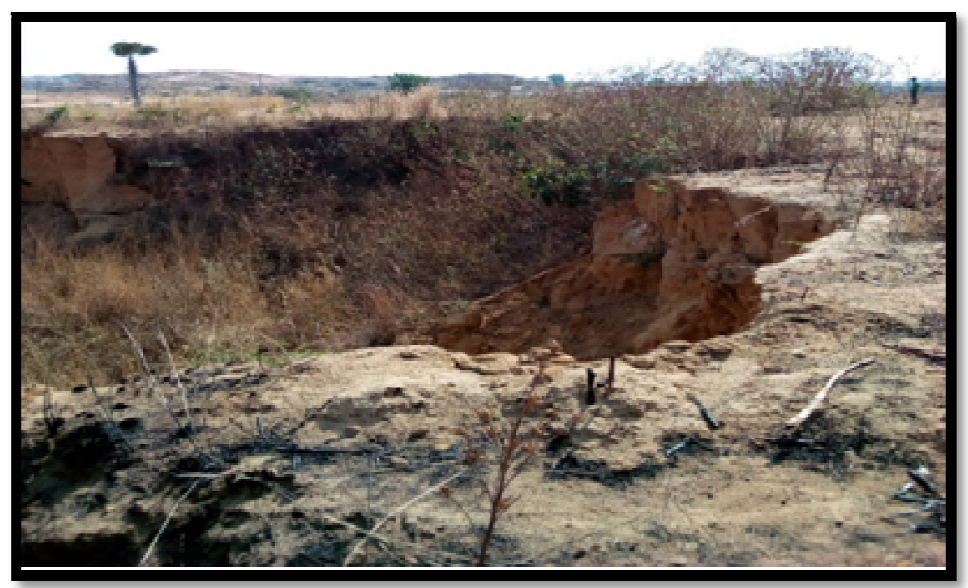

Figure 2: Expansion of a Gully at Site

Source: Researchers' Field Work, 2018

The following processes causes expansion of gullies these are raindrop impact, tunneling in dispersive soil, spalling, slaking , trickle flows, gully head advancement, basal sappingetc.

\section{Methodology}

Data was drawn from primary and secondary sources. The secondary data involves the use of information already in existence and this was sourced largely through literature review. Primary data used was acquired through field survey, and case study method.

\subsection{Topography of Jos Plateau}

Plateau state is located in Nigeria's middle belt with an area of $26,899 \mathrm{~km} 2$. The state has an estimated populated of about three million people. The state is named after the picturesque Jos Plateau. A mountainous area is the north of the state with captivating rock formation. Bare rocks are scattered across the grasslands, which cover the Plateau. The altitude ranges from around 1,200 meters (about 4000 feets) to a peak of 1,829 meters above sea level in the shore hills ranges near Jos (Rengel, 2003) as cited by Ugorji, (2018). Figure 3 shows the location of Jos,Plateau State in Nigeria. 


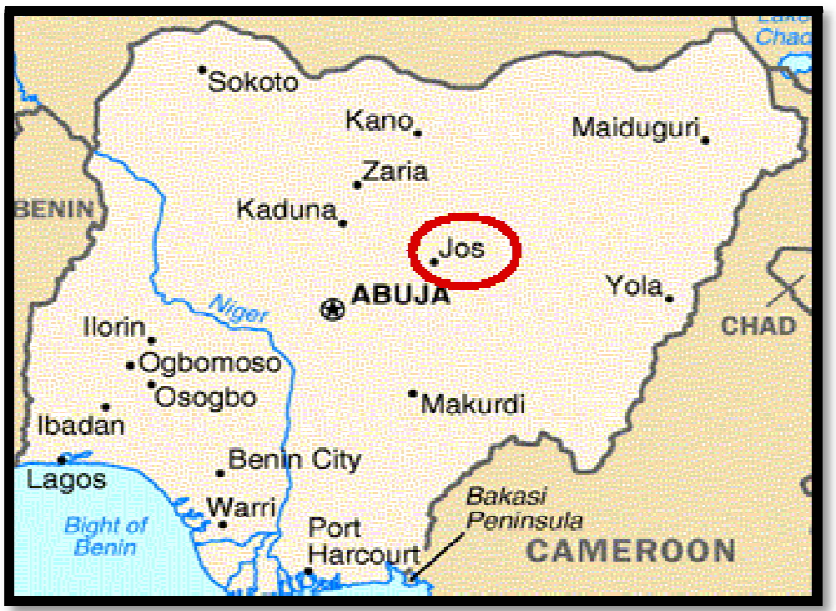

Figure 3: Map of Nigeria showing Jos, Plateau State Capital in Sphere Source: http:/ / www.plateaustategov.org/ visit/ jos.html

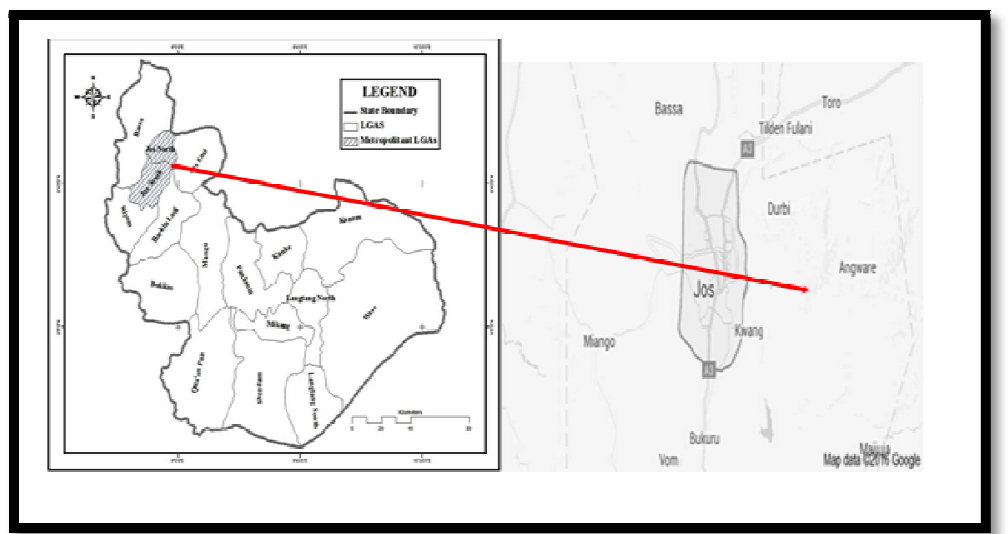

Figure 4: Jos Metropolitan Local Government Areas, Map of Jos

Source: Adapted from Sati, 2015.Source: Adapted from Okoronkwo, 2017

\subsection{Case Study - Tudun Wada Community}

Geographically, Tudun Wada is located at Domkat Bali/Tudunwada ring road (Junction) in Jos North L.G.A of Plateau State. The site area was computed to be 49.0982hectare (121.327acres) using the data from the site survey. This settlement is accessed through the old airport junction on Yakubu Gowon way, via Domk at Bali road and through the city centre via Tudun wada road with poor setbacks and airspaces which would have helped in curbing the effect of fire outbreaks. Figure 2 shows the aerial layout map of the settlement while Figure 5 shows the study area in detail.

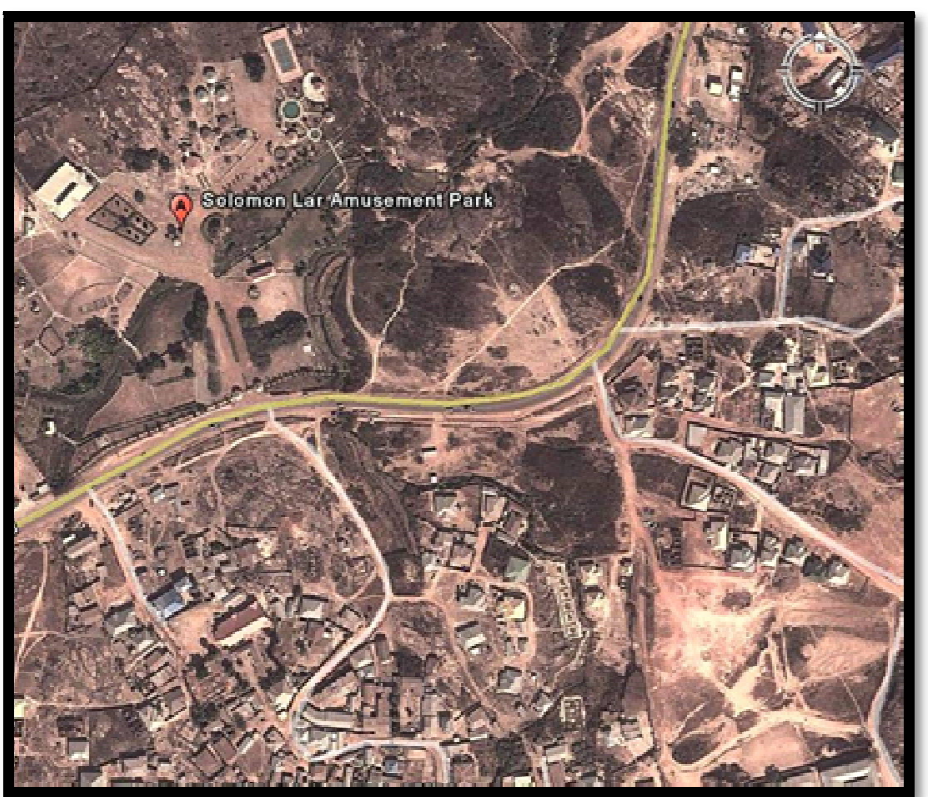

Figure 5: Aerial View of Tudun Wadaat Domkat Bali/ Tudunwada Ring Road (Junction) In Jos

Source: Google Earth Images, 2016 


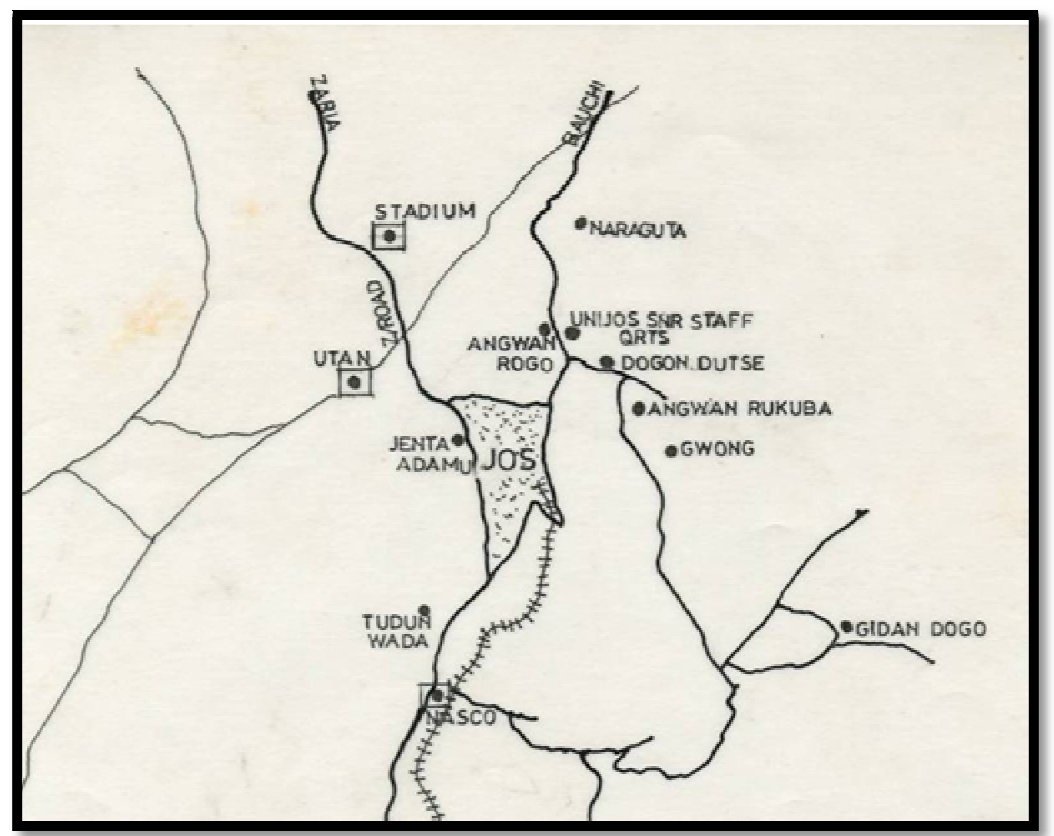

Figure 6: Map Showing the Study Area (Tudun Wada) Circled in Red Colour Source: Pubs.Sciepub.Com, 2016

\subsection{Reconnaissance Survey}

The site was visited and a reconnaissance survey carried out, subsequently, various surveys were carried out from which the following has been deduced after comparing and complementing primary data taken from site with other secondary data Prevailing Conditions at Inception of Design Intervention

\subsection{Topography}

The topography of the site is a complex form that was forged gradually by erosion on the area which has been battered by mining activities, so a sketch was made of the contour on the survey map from data (elevation) take by the use of a hand held Geographical Positioning System device (GPS). The altitude of major land forms were taken and supplemented with computer generated coordinates and altitude from satellite imagery (Google earth 2016) for a wider coverage and precise space analysis in the course of the design process. Figure 7 and v shows the rock formation on and off site depicting the topography of the area

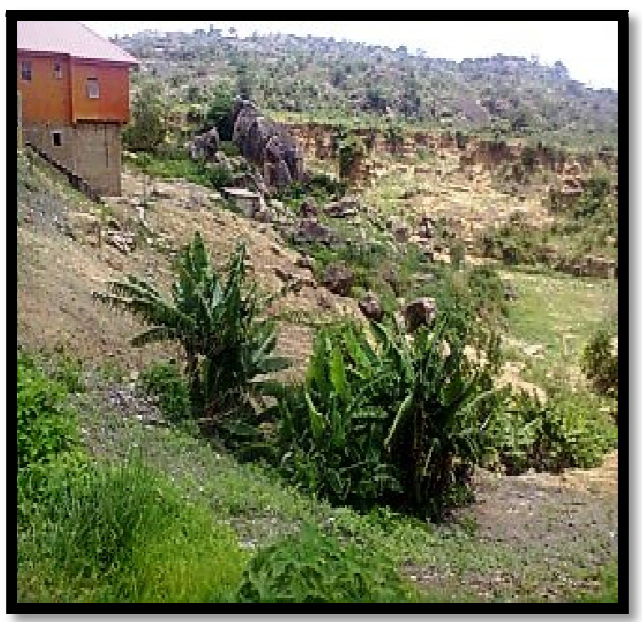

Figure 7: Topographic View from Off-Site Source: Researchers' Field Work, 2018 


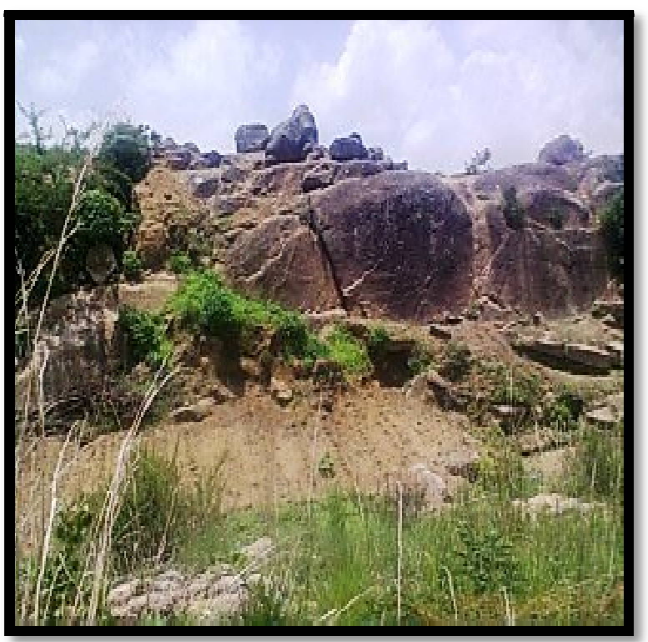

Figure 8: Topographic View from on Site Source: Researchers' Field Work, 2018

\subsection{Erosion Menace}

Figure 9 toFigure11 shows the reality of erosion menace and mining activities on the Jos Plateau which has led to less productive and continuous deteriorating land mass within the study area.

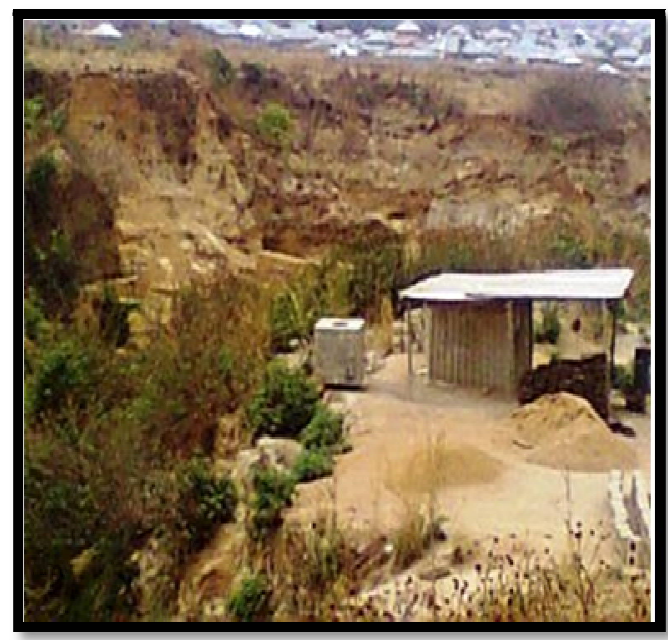

Figure 9: A Deep Gully Located on Site Source: Researchers' Field Work, 2018

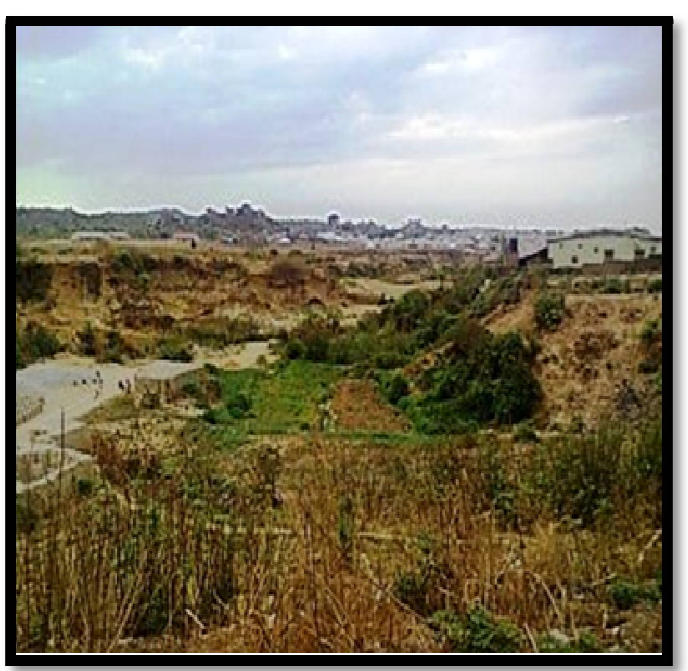

Figure 10: The reality of Erosion Menace on site Source: Researchers' Field Work, 2018 


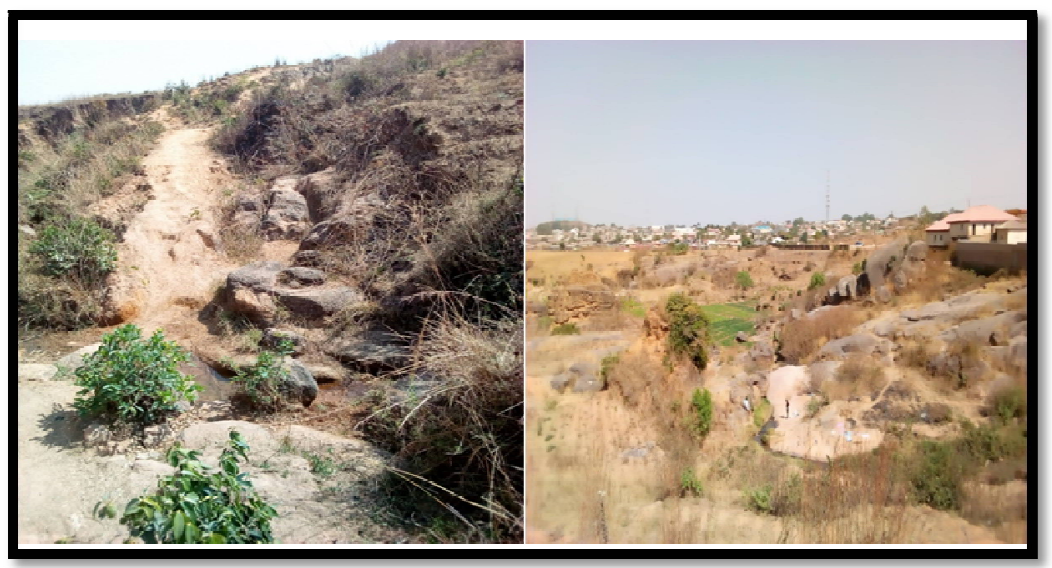

Figure 11: Gully Eroded and Deteriorating Land Mass on Site Source: Researchers' Field Work, 2018

\subsection{Drainage}

The site is undulating and has its drainage in different directions according to the land form (topography), with the greater part of the runoff flowing to the lowest part of the site; most of this runoff is channeled by existing water path on the site. Photographic images can be seen in Figure12 and Figure13

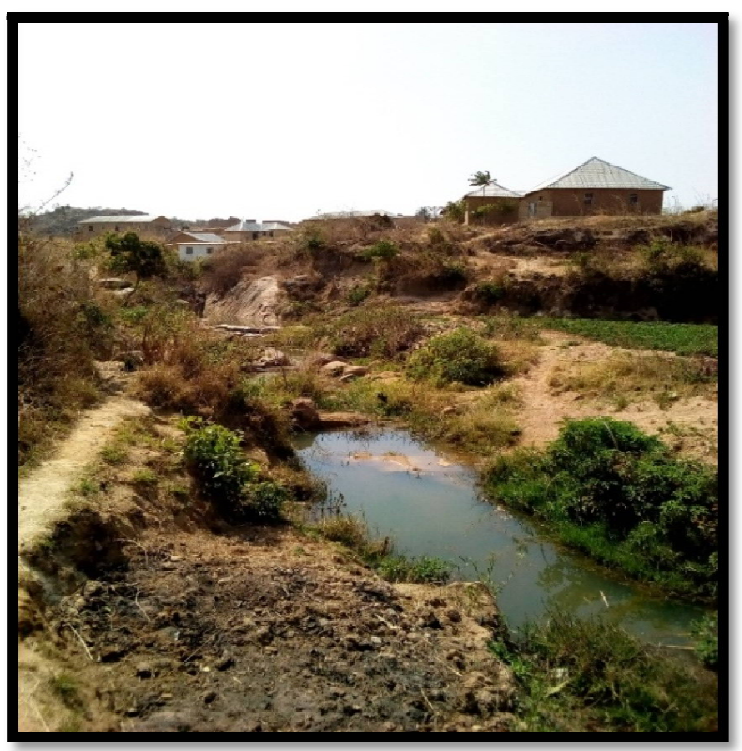

Figure12: Minor Water Way on Site Source: Researchers' Field Work, 2018

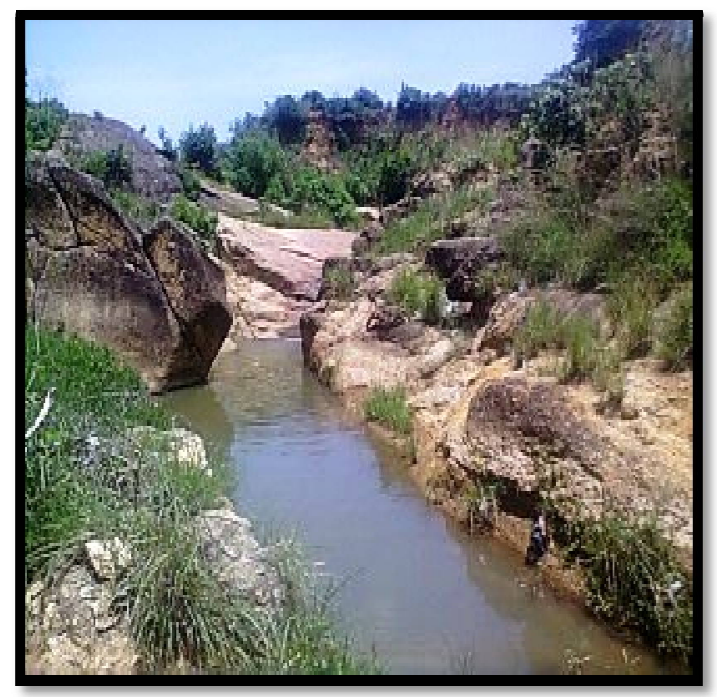

Figure 13: Drainage Channel within the Gully Eroded Site Source: Researchers' Field Work, 2018 


\subsection{Soil Survey}

Information obtained through the 'Feel Method Test' for the soil on site to be predominantly laterite, clay and clay-loam, distributed throughout the site with no defined pattern. Soil erosion is a major environmental problem on the site. Tin mining, in its heyday, rendered some localities around the site more susceptible to soil erosion. Today, however, the soil erosion menace is being accentuated largely by lack of maintenance of green surfaces which has resulted in gullying along the numerous paths which criss-cross the Tudun-wada area surface as revealed in Figure14 and Figure15.

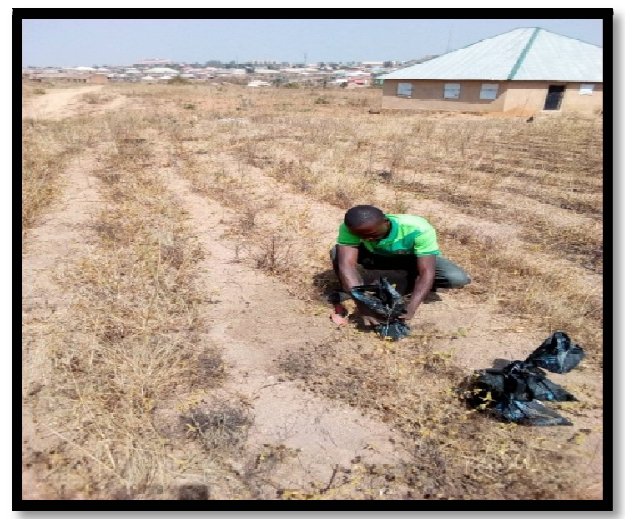

Figure 14: Soil on Site

Source: Researchers' Field Work, 2018

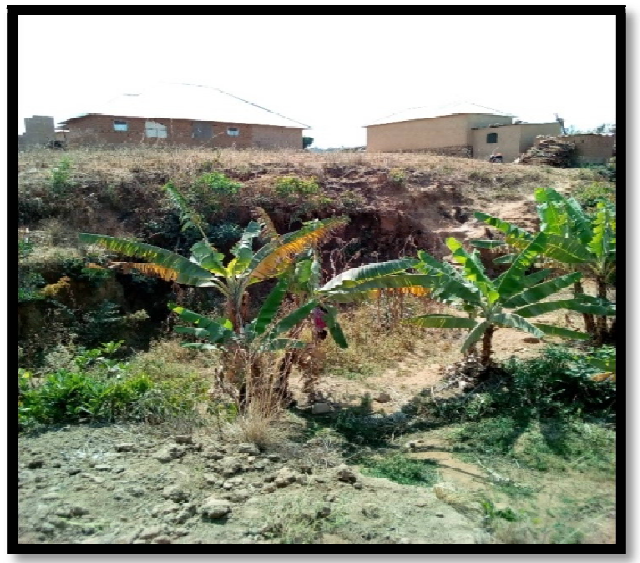

Figure 15: Soil Type in the Gully Eroded Site

Source: Researchers' Field Work, 2018

\subsection{Vegetation}

The vegetative cover of the site is predominantly shrubs and grass; parts of the site are planted up with agricultural crops during rainy season and irrigation is used during the dry season to support vegetable production on some parts of the site. There are very few trees on the site. Photographic illustrations can be seen in Figure16 and Figure1 7.

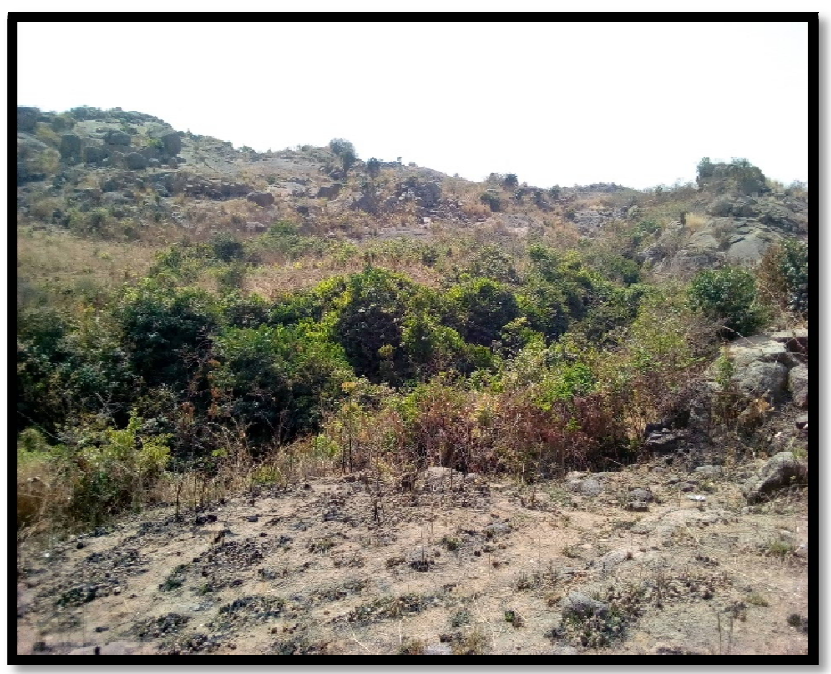

Figure16: Shrubs and Grass on Site

Source: Researchers' Field Work, 2018 


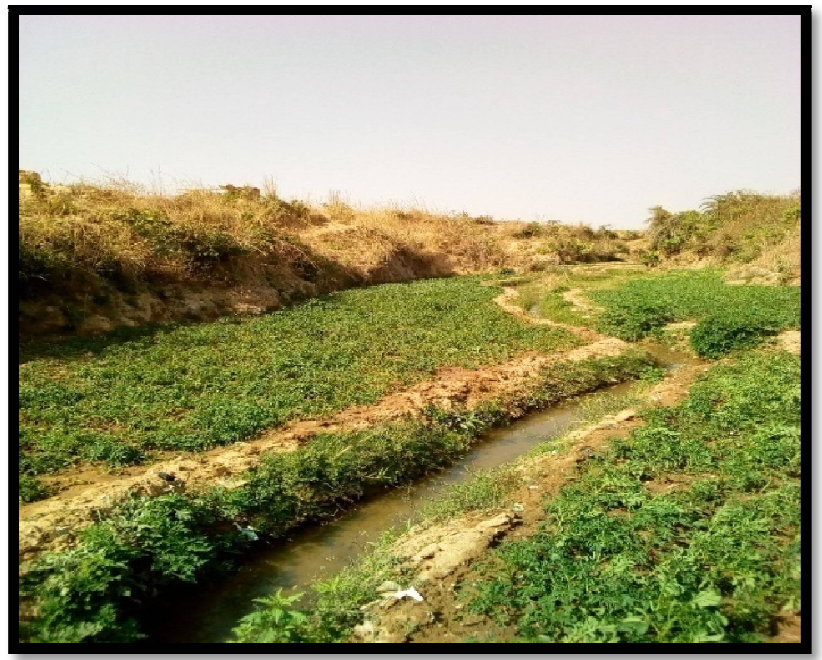

Figure 17: Cultivation of Agricultural Crops on Site

Source: Researchers' Field Work, 2018

\subsection{The Proposal}

\subsubsection{The Approach}

In the course of our field survey, both positive and negative aspects of the site were observed and we translated them into an Analysis Chart as seen in Table 1.

\subsubsection{Zoning}

The site was zoned into seven parts bases on the topography of the site, this zone has introduced simplicity as seen in Figure 5.

\subsubsection{Conceptual Designs}

The researchers proposed the development of three conceptual plans (with conceived spaces for the landscaping) from which the most preferred was selected using the "Grade Score Table" in Table 2.Conceptual plan two was the most preferred based on aesthetics, circulation, economy, and functionality, and was developed fully by imputing required details and scale to bring it through an evolutionary process from concept to Landscape Master Plan toresuscitate the degraded landscape to a sustainable design as seen in Figure 6.

\begin{tabular}{|c|c|c|c|c|c|c|}
\hline $\mathbf{S} / \mathbf{N}$ & Element & $\begin{array}{c}\text { Coverage } \\
\mathbf{m}^{2}\end{array}$ & Condition & Opportunity & Constraint & Remark \\
\hline 1 & Entrance & 35 & Poor & No & Non & Modify \\
\hline 2 & Terrain & - & Poor & Yes & Non & $\begin{array}{l}\text { Modify by grading } \\
\text { and installation for } \\
\text { planting }\end{array}$ \\
\hline 3 & Trees & & Poor & Yes & Non & Retain \\
\hline 4 & Water way & 471 & Poor & Yes & Non & Modify \\
\hline 5 & Water body & 2827.8 & Poor & Yes & Non & Modify \\
\hline 6 & Rocks & 22696.77 & Poor & Yes & Non & Retain \\
\hline 7 & Shrubs & 231 & Poor & Yes & Non & Modify \\
\hline 8 & Ground cover & & Poor & Yes & Non & Modify \\
\hline 9 & Shade trees & 12 & Poor & Yes & Non & Modify \\
\hline 10 & Farm & - & Poor & Yes & Non & Relocate \\
\hline 11 & Access road & & Poor & Yes & Non & Modify \\
\hline 12 & Fence & 41 & Poor & Yes & Non & Replace \\
\hline 13 & Gullies & 18072 & Poor & Yes & Depth & Modify \\
\hline 14 & $\begin{array}{l}\text { Foot path on } \\
\text { rock }\end{array}$ & & Poor & Yes & Non & Retain \\
\hline 15 & Valleys & 42024 & Poor & Yes & size & Modify \\
\hline 16 & Building & 135.88 & Poor & Yes & position & Modify \\
\hline
\end{tabular}

Table 1: Summary of Analysis Chart Table

Source: Researchers' Design, 2018 


\begin{tabular}{|c|c|c|c|c|c|}
\hline Concept(s) & Aesthetics & Circulation & Economy & Functionality & Total \\
\hline 1 & 4 & 4 & 4 & 3 & 15 \\
\hline 2 & 5 & 5 & 3 & 4.5 & 17.5 \\
\hline 3 & 2.5 & 4 & 4 & 3.5 & 14 \\
\hline
\end{tabular}

Table 2: Grade Score Table

Source: Researchers' Design, 2018

\subsubsection{Landscape Master Plan}

The master shows a graphic presentation of the finished design, with a degree of detail as presentable on a scale of 1:1000. The master plan shows among others, the visual spatial relationship between spaces and a various facilities and network of pedestrian and vehicular circulation routs. The plants as proposed in the planting scheme are represented especially by the various plant canopies, while drainage systems are also evident. The master plan shows the three main parts / zones of the site clearly with different mode of demarcations and linkages thereby revealing the interrelated concept of the proposed landscape design to uphold sustainability. Figure 7-Figure9 highlights the developed landscape master plan.

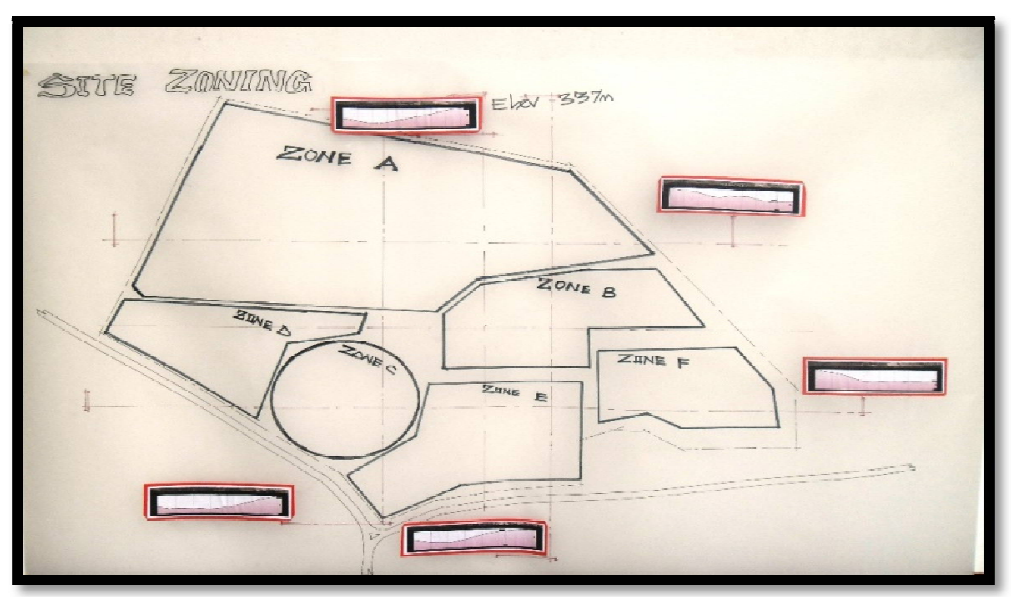

Figure 18: Site Topographic Zoning Concept

Source: Researchers' Design Drawing, 2018

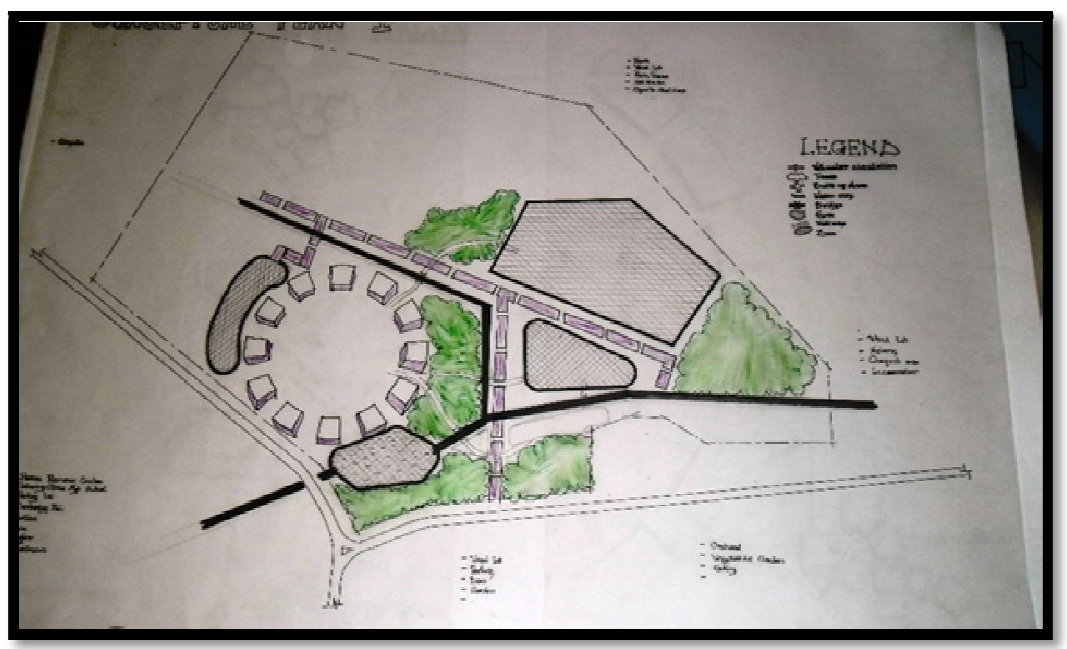

Figure 19: Preferred Conceptual Plan

Source: Researchers' Design Drawing, 2018 


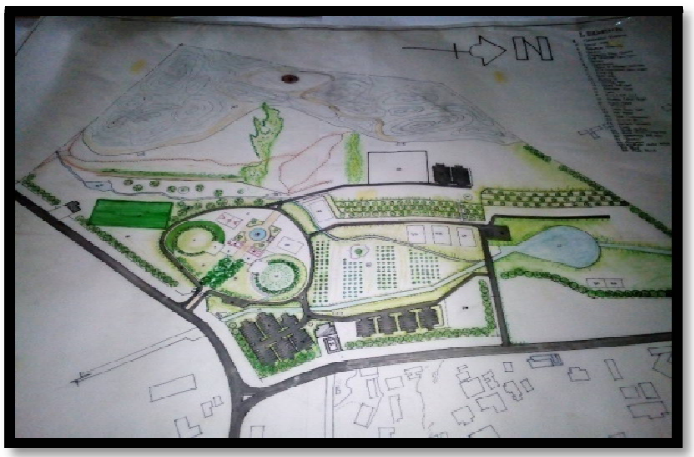

Figure 20: Landscape Master Plan

Source: Researchers' Design Drawing, 2018

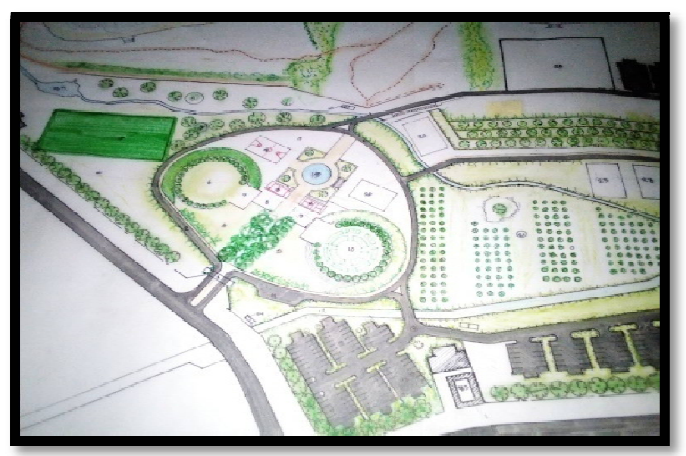

Figure 21: A Detailed View of the Landscape Plan Source: Researchers' Design Drawing, 2018

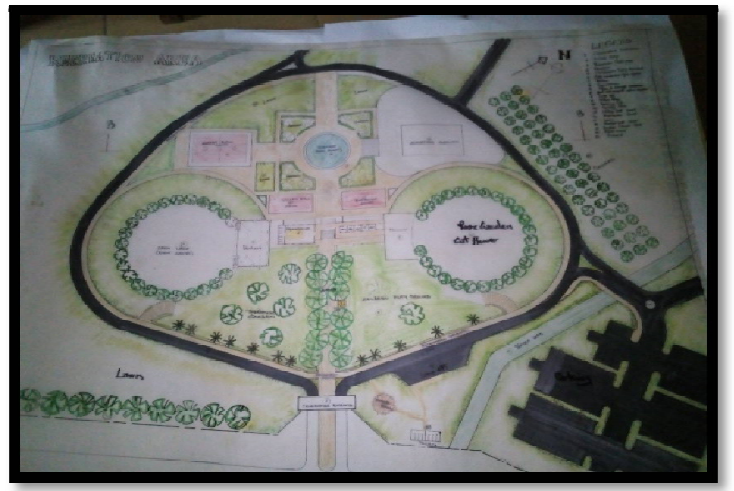

Figure 22: An Enlarged View of the Recreation Area Source: Researchers' Design Drawing, 2018

3.10. Catalogue of the Proposed 3D Model and Its Finishing

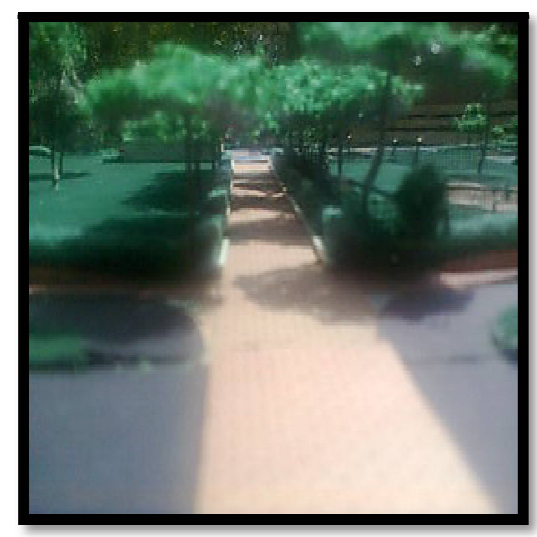

Figure 23: Entrance Avenue

Source: Researchers' 3D Model, 2018 


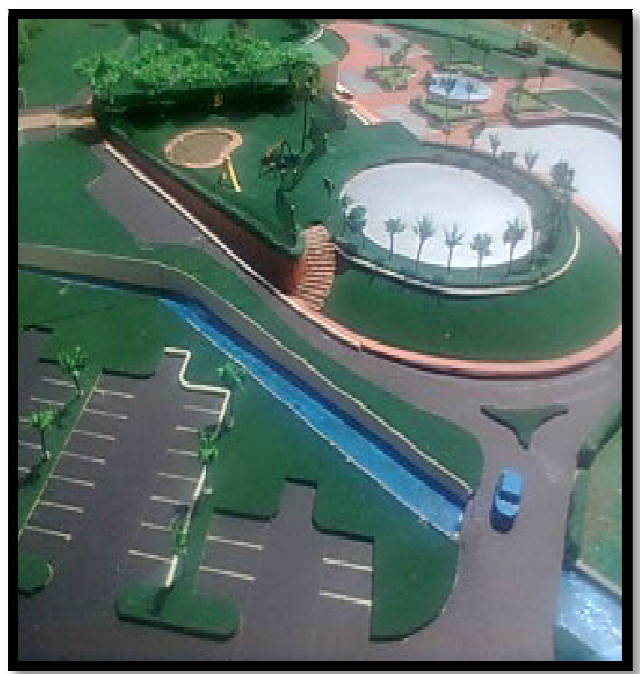

Figure 24: Car Parking Lot

Source: Researchers' 3D Model, 2018

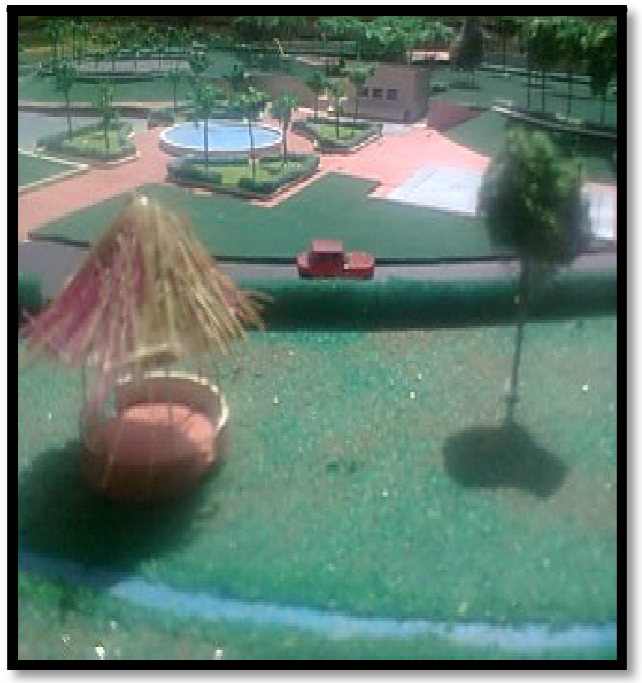

Figure 25: Landscape View

Source: Researchers' 3D Model, 2018

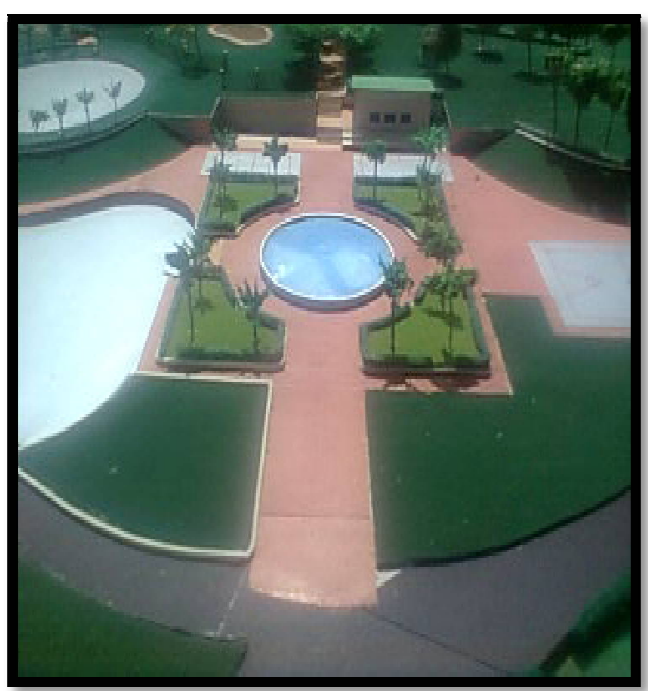

Figure 26: Open Courtyard

Source: Researchers' 3D Model, 2018 


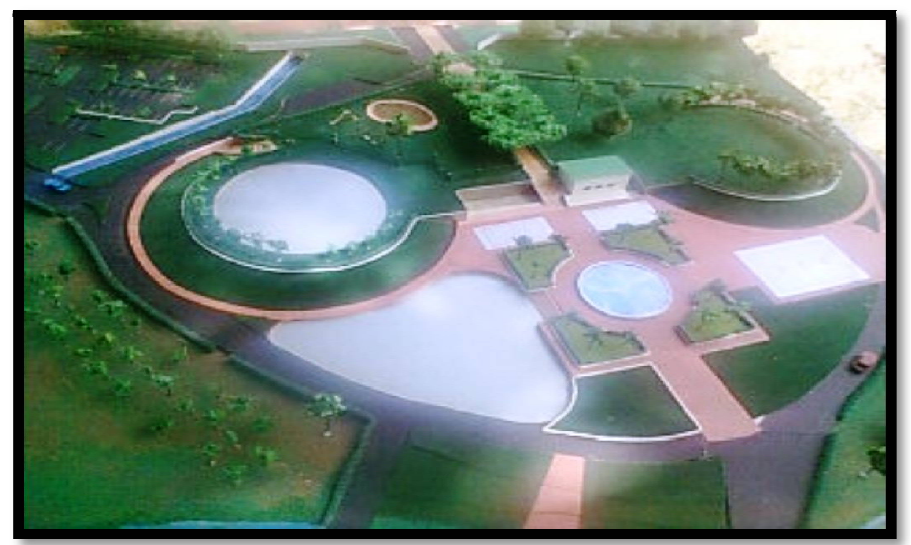

Figure 27: Landscaped Model with Proposed Facilities Source: Researchers' 3D Model, 2018

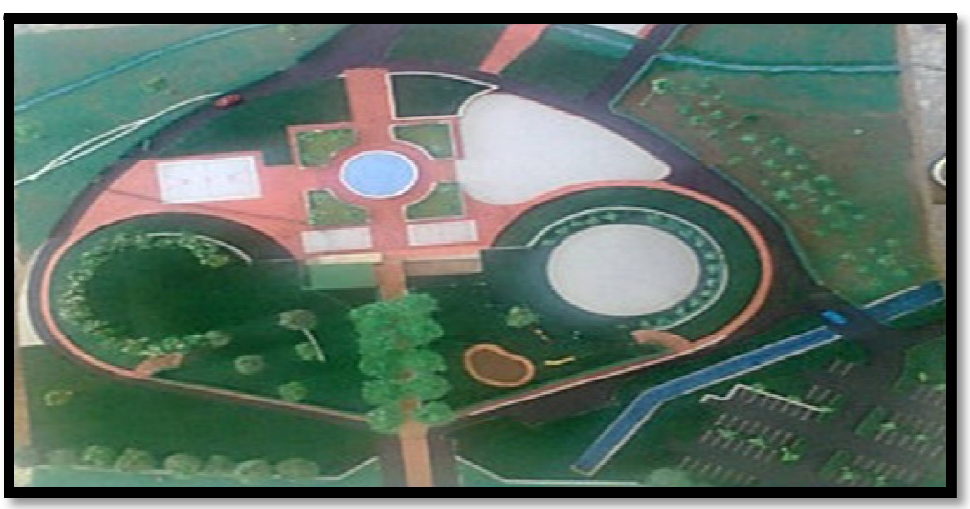

Figure 28: Ariel Perspective

Source: Researchers' 3D Model, 2018

\section{Recommendations}

Understanding the unique nature of a landscape terrain and its characteristics, environmental factors such as gully formation, flooding, etc. necessitates the following recommendations.

- Improving vegetation cover "surface cover" with trees, shrubs should be used in mitigating erosion where grazing is likely to occur and restricting stock access.

- Land reclamation measure such as construction of retaining walls, fencing, and construction of deep and wide drainage systems to channel volumes of water to safe discharge points should be given priority.

- Planting erosion resistant grass such as carpet grasses (Axonopus spp.), vetiver grass with deep roots, Bermuda grass (Cynadon dactylon), Zoysia grass (Zoysia tenuifolia) to compliment the role of vegetation.

- The control of gullies through agro forestry practice should be imbibed as these trees and its yield can be used to generate income for the inhabitants of affected communities.

- Government initiatives and trends should be developed so as to constantly check that the needs of recreational facilities are provided and such facilities which would be bedrock/ foundation to private establishments/ firms as present times defines the essence of living by recreation and leisure.

This recommendation provides an intervention strategy for improving vegetation cover at the site and combating the scourge of erosion menace.

\section{Conclusion}

This paper discussed landscape design for Tudun-Wada areas affected by gully erosion in Jos, Plateau State. Field study had shown that mining activities and erosion are the major contributors to the degraded landscape of the community. The proposed design and plan encourage conservational, recreational (active and passive), educational, cultural, and environmental values to the immediate community taking into account ecological principles and human need for greenery/ open space. Furthermore, Governments at all levels should collaborate tofind a lasting solution to the phenomenal by adopting recommendations contained in this study as well as integrating other ones not mentioned here but would complement the efforts of a holistic tackling of the menace.

\section{References}

i. Adegbie, M.O. \&Ayeni, D.A.(2013).Soft Landscape Elements: Importance and Implications on Thermal Control in Tropical Buildings. International Journal of Development Research, 3(5),pp.055-060

ii. Adekunle, OJ. \&Basorun, J.O. (2016). The Evolving Roles of Landscaping in Campus Space Manage- ment: Ekiti State University, Ado-Ekiti, Nigeria in Focus. Journal of Environmental Protection.7, 1380-1388. 
iii. Ajayi, M.; Adegbie, M. \& Omole, F. (2016). Landscaping and Sustainable Housing Development in Akure, Nigeria. In Ebohon, O. J., Ayeni, D. A, Egbu, C. O, and Omole, F. K. Procs. of the Joint International Conference (JIC) on 21st Century Human Habitat: Issues, Sustainability and Development, 21-24 March 2016, Akure, Nigeria, pp 958-964

iv. Ayeni, D. A. (2012). Emphasizing Landscape Elements as Important Components of aSustainable Built Environment in Nigeria. Developing Country Studies 2(8),pp.33-42

v. Ayeni, D. A.(2012). Enhancing and Developing Sustainable Tourism through Landscaping in Nigeria. Unpublished Ph.D. Thesis, De Montfort University, Leicester, United Kingdom.

vi. Central Public Works Department (2013). A Handbook of Landscape - A Guide. New Delhi.

vii. Dung-Gwom, J. Y. (2007).Urban Renewal in Jos - Bukuru Metropolis. Paper Presented at the Nigerian Institutions of Estate Surveyors and Valuers, MCPD Workshop on: Housing Delivery, Urban Renewal in Jos - Bukuru Metropolis Problems and Prospects.25/ 10/ 2007.pp 2-17.

viii. Igwe P.U., Chinedu O.C., Nlem E.U., Nwezi C.C., \&Ezekwu J.C., P. (2018). A Review of Landscape Design as a Means of Controlling Gully Erosion. International Journal of Environment, Agriculture and Biotechnology (IJEAB) 3(1), 103-111.

ix. Okoronkwo, N.C. (2017). Proposed landscape re-design for Jos city centre. Unpublished HND Thesis, Federal College of Forestry, Jos.

x. Olatunde, O. (2005). Basic Principles of Site Selection and Planning. Penthouse Publications (Nig)

xi. Sati, Y. C. (2015). User Perception of Green Spaces in the Context of Architectural Composition of Jos Metropolis, Nigeria.Journal of Environment and Earth Science.5 (18), 74-101.

xii. Soil conservation guidelines for Queensland (3rd ed.), (2015).Gully Erosion and its controlChapter 13 in:pp 1-80.

xiii. The challenge of slums: global report on human settlements, 2003 / United Nations Human Settlements Programme. Earth scan Publications Ltd.

xiv. Ugorji, V. (2018). Assessment of some selected properties of agricultural soils in Kadama area of the Jos Plateau. Unpublished ND Thesis, Federal College of Forestry, Jos.

xv. UN-Habitat Report, (2007).Slum Dwellers to double by 2030Archived 2013-03-17 at the Wayback Machine

xvi. United Nations, (2007). The Millennium Development Goals Report.Link. pp 26

xvii. University of Jos (Rev.ed.), (2017). Guidelines for preparation and submission of theses and dissertations and issues in quality research enhancement. Jos: School of Postgraduate Studies. 